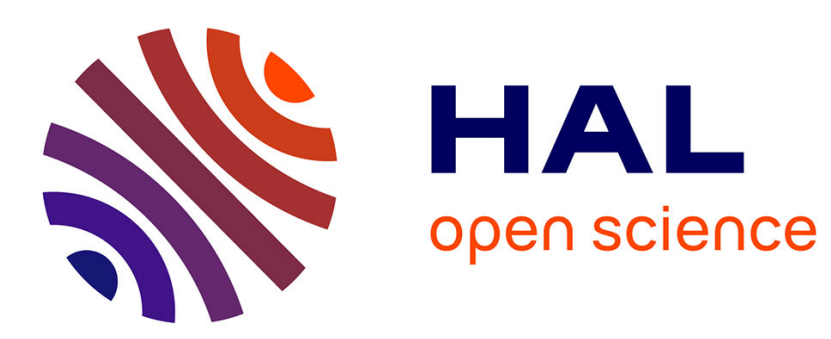

\title{
Tentative estimation of chloroplast and non chloroplast proteins of the leaves of a plant biomass
}

Roger Douillard

\section{To cite this version:}

Roger Douillard. Tentative estimation of chloroplast and non chloroplast proteins of the leaves of a plant biomass. 6. International congress on photosynthesis, Aug 1983, Bruxelles, Belgium. hal02781574

\section{HAL Id: hal-02781574 \\ https://hal.inrae.fr/hal-02781574}

Submitted on 4 Jun 2020

HAL is a multi-disciplinary open access archive for the deposit and dissemination of scientific research documents, whether they are published or not. The documents may come from teaching and research institutions in France or abroad, or from public or private research centers.
L'archive ouverte pluridisciplinaire HAL, est destinée au dépôt et à la diffusion de documents scientifiques de niveau recherche, publiés ou non, émanant des établissements d'enseignement et de recherche français ou étrangers, des laboratoires publics ou privés. 


\section{Advances in Photosynthesis Research}

Proceedings of the Vlth International Congress on Photosynthesis. August 1-6, 1983. Brussels, Belgium

Edited by C. SYBESMA

ADVANCES IN AGRICULTURAL BIOTECHNOLOGY

The majority of the invited contributions are review papers, summarizing and putting into perspective the latest results of research in a particular area; the other contributions comprise research papers giving details on specific aspects. "Advances in Photosynthesis Research", therefore, is an important document. containing the latest high-level information about photosynthesis in its broadest sense. The four volumes are of considerable value as a reference source for scientists active in the field and others wishing to be informed about recent developments. Furthermore, these volumes will prove to be important as a means of background study for those entering this exciting and promising field of investigation.

1984. $3480 \mathrm{pp}$. in 4 volumes

ISBN 90-247-2946-7

Df1. $1.250,00 /$ US $\$ 478.00 / £ 317.50$

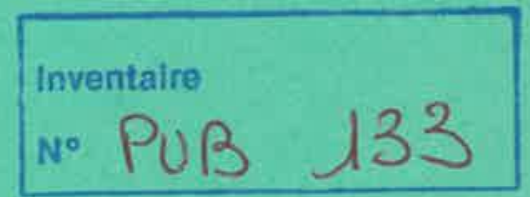

MARTINUS NIJHOFF/DR W. JUNK PUBLISHERS A Member of the Kluwer Academic Publishers Group P.O. Box 566, $2501 \mathrm{CN}$ The Hague, The Netherlands 


\section{NEW AND FORTHCOMING PUBLICATIONS}

\section{Photosynthesis Research}

an international journal

ISSN 0166-8595

Editor-in-Chief

DR. MARCELLE

Laboratory of Plant Physiology

Research Station of Gorsem

Brede Akker 3

B-3800 Sint Truiden, Belgium

Tel.: 011-682019
Associate Editor

DR. GOVINDJEE

Depariment of Plant Biology

UIUC

289 Morrill Hall

505 South Goodwin Avenue

Urbana, Illinois 61801 (USA)

Tel.: (217) 333-1794

The consulting Editorial Board consists of approximately 30 members

\section{Aims and Scope}

Photosynthesis Research aims to provide a forum for original papers dealing with photosynthesis without imposing an artificial division between fundamental and applied research. Our aim is to cover all aspects of photosynthesis research starting from the primary reactions and going as far as the energy from biomass. 'Topics acceptable for publication could include primary reactions, electron transport, photophosphorylation, earbon assimilation, regulatory phenomena, environmental and ecological aspects of photosynthesis, photorespiration, $\mathrm{CO}_{2}$ fixation in CAM plants, and bacterial and algal photosynthesis, although one should not feel restricted just to these topics.

In the case of artificial sustems, the authors should be able to judge for themselves whether to publish in a photosynthesis or photobiology journal. In the case of doubt, the Editorial Board can help the author in making this decision.

Papers will be considered for publication at all levels of plant organization: subcellular, cellular, whole plant and canopy levels.

Manuscripts submitted for publication are always reviewed by two referees, not necessarily memiers of the Editorial Bosrd, and chosen for their competence in the field covered by the paper. The appeal to people who are not members of the Editorial Board is necessary in order to cover the whole field of photosynthesis.

Call for papers

Authors who wish to contribute to Photosynthesis Research are invited to send their manuscripts or requests for "Instructions to Authors". Manuscripts from North America should be sent to Dr. Govindjee, from all other areas to Dr. Marcelle.

Subscription information

Vol. 5, 1984 (4 issues): For institutions, Dfl. 165.00 (US $\$ 66.00$ ), plus Dfl. 25.00 (US\$ 10.00) for postage and handling. For individuals, Dfl. 100.00 (US\$ 40.00 ) including postage and handling.

\section{Available at the end of 1984}

\section{Photosynthesis During Leaf Development}

Edited by Z. SESTAK

This unique monograph was written by nine seientists from the Department of Physiology of Photosynthesis and Water Relations of the Institute of Experimental Botany, Czechoslovak Academy of Sciences in Prague. They based it on a choice of papers from the vast literature, which was not always easy to assess, and on the 20 years pioneering research experiences of their laboratories. 
TENTATIVE ESTIMATION OF CHLOROPLAST AND NON CHLOROPLAST PROTEINS OF THE LEAVES OF A PLANT BIOMASS

\section{R. DOUILLARD}

\section{INTRODUCTION}

The membranous proteins of lamellae and the soluble proteins of chloroplast stroma account for nearly all the proteins in leaves (Joyard, 1979). Agriculture productivity relies on these proteins in different ways. First, the biosynthesis of sugars from carbon dioxide, water and light, depends on them since they are building blocks of the photosynthetic apparatus. Second, they are part of several crops such as vegetables, fodder or leaf protein concentrate ; the quality and value of these crops depend obviously on leaf proteins. It is thus clear that leaf protein composition is an essential data in plant physiology and ecology or in plant breeding and agriculture.

In this communication a model is presented which takes into account RuBPcase turnover number and content in leaves of $C_{3}$ and $C_{4}$ type plants and relates leaf protein weight to net and gross primary production of a canopy.

\section{MODEL DESCRIPTION}

The principle of the derivation relating the number $\mathrm{N}$ of RuBpcase molecules of a canopy to the carbon weight it may assimilate during a year (CW) has been given by Ellis (1979) :
$\mathrm{CW}=\mathrm{N} \cdot \tau \cdot \mathrm{TN} \cdot 12$
(Abbreviations in table I)

12 is the atomic weight of carbon.

TABLE I. Abbreviations and numerical values

CW : annual gross. fixation of carbon by a plant biomass ; for land plants of the Earth, CW is estimated to equal two times the net fixation (Box, 1977), that is $2 \times 53 \cdot 10^{15} \mathrm{~g}$ (Woodwell, 1978).

LP : leaf protein weight of a plant biomass.

MRuBPcase : molecular weight of RuBPcase, estimated at $5.5 \cdot 10^{5}$ daltons (Yeoh et al., 1982).

$\mathrm{N}$ : number of RuBPcase molecules of a plant biomass.

RuBPcase : ribulose 1,5-bisphosphate carboxylase/oxygenase.

TN : turnover number of RuBPcase (kat-mole ${ }^{-1}$ ) ; see table III.

$\rho$ : ratio of leaf protein weight to RuBPcase weight in a plant biomass ; see table II.

$\tau$ : duration of enzyme activity in one year.

$i$ : index defining an homogeneous type of plant in a specified climatic area.

3 and 4 : indexes corresponding to $C_{3}$ and $C_{4}$ plants.

For the whole world $\mathrm{N}$ may thus be calculated as follows :

$\mathbf{N}=\frac{1}{12} \sum_{1}^{i} \frac{C W_{i}}{\tau_{i} \cdot T N_{i}}$

Sybesma, C. (ed.), Advances in Photosynthesis Research, Vol. IV. ISBN 90-247-2945-9.

(C) 1984 Martinus Nijhoff/Dr W. Junk Publishers, The Hague/Boston/Lancaster.

Printed in The Netherlands. 


\section{IV.2.166}

Each $i$ defines an homogeneous type of plant in a specified climatic area. Leaf protein weight is thus given by :

LP $=\frac{\text { MRuBPcase }}{12} \sum_{1} \frac{\mathrm{CW}_{i}}{\tau_{i} \cdot \mathrm{TN}_{i}} \rho_{i}$

where it is assumed, according to Yeoh et al. (1982) that RuBPcase molecular weight is rathex constant among various plant species. Formula (3) raises nevertheless the question of the choice of plant types and of climatic areas. An example is shown below.

TABLE II. Protein (LP) and RuBPcase content of leaves; DM : dry matter of leaves ; $\rho=I P / R u B P c a s e . ~(a)$ : Singer et al. (1952) ; (b) : Pheloung, Brady (1979).

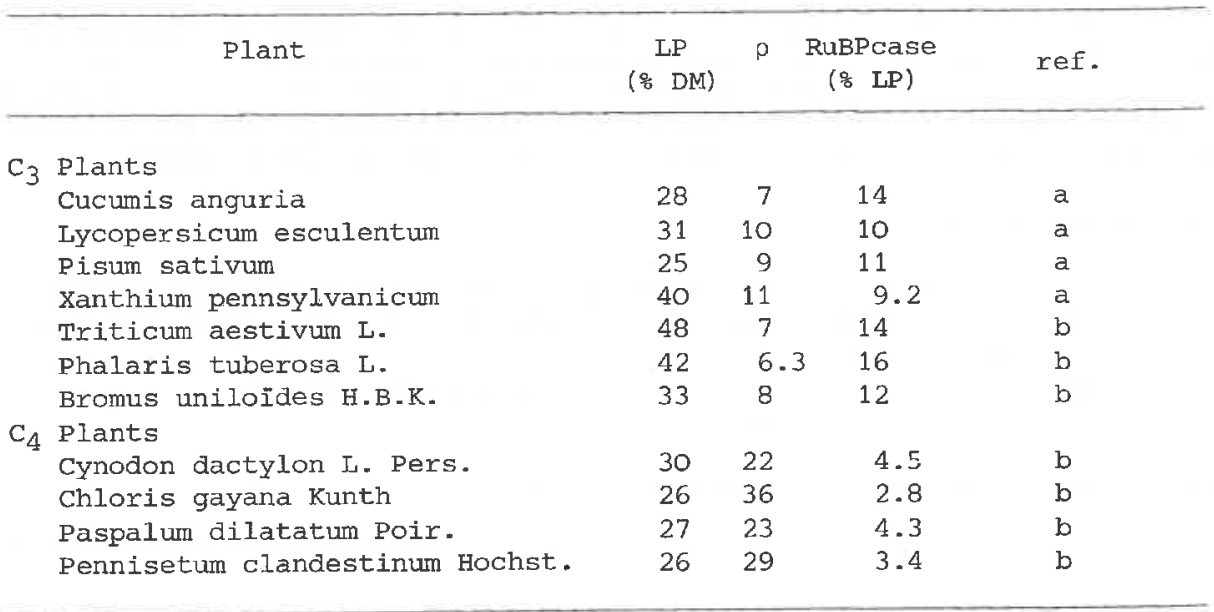

\section{LEAF PROTEIN WEIGHT OF THE EARTH LAND PLANTS}

In this example, a single climatic area is considered but a distinction is made between $\mathrm{C}_{3}$ and $\mathrm{C}_{4}$ plants. Thus :

$\mathrm{LP}=\frac{\mathrm{MRuBPcase}}{12 \cdot \tau}\left(\frac{\mathrm{CW}_{3}}{\mathrm{TN}_{3}} \cdot \rho_{3}+\frac{\mathrm{CW}}{\mathrm{TN}_{4}} \cdot \rho_{4}\right)$

As shown in Tab II, $\rho_{3}$ ranges from 6 to 11 and $\rho_{4}$ from 22 to $36 . p_{4}$ is thus about 3 times higher than $0_{3}$. On the other hand, the turnover number (TN) is limited in vivo by the non saturating carbon dioxide amount (Ellis, 1979 ; Wildner, 1981 ; Tab. III). In fact, this amount is much higher in the bundle sheet cells of $C_{4}$ type plants, where RuBPcase works, than in $C_{3}$ type plant cells (Ku, 1979): $\mathrm{TN}_{4}$ is thus clearly higher than TN3. For these reasons, it is admissible that the ratios $\rho_{3} / T^{2} N_{3}$ and $\rho_{4} / T_{4}$ have similar values. Since $\mathrm{CW}_{3}+\mathrm{CW}_{4}=\mathrm{CW}$, the relation (4) may be written as follows :

$\mathrm{LP}=\frac{\text { MRuBPcase }}{12 \cdot \tau} \mathrm{CW} \frac{\rho_{3}}{\mathrm{TN}_{3}}$

CW, the gross primary fixation, equals at earth scale, about two times the net primary fixation of carbon dioxide by land plants (Box, 1977). The difference 
between gross and net productivity is accounted for by dark respiration. Dark respiration estimated in various conditions and for numerous plants ranges indeed from 20 to 70 \% of gross primary photosynthetic productivity (Kira, 1975; Yamaguchi, 1978 ; Ruget, 1981 a and b). Photorespiration is neglected in this estimation.

$\tau$, duration of enzyme activity during a year greatly depends on the plant and on the climatic area. It is estimated to be 0.3 year or $9.5 \cdot 10^{6}$ sec. The amount of leaf protein in the land plants of the Earth is thus (data of Tab. I,II and III) :

$$
\begin{aligned}
& \text { LP }=\frac{5.5 \cdot 10^{5}}{12 \cdot 9.5 \cdot 10^{6}} 2 \cdot 53 \cdot 10^{15} \frac{6 \text { to } 11}{1 \text { to } 3.3} \mathrm{~g} \\
& \mathbf{L P}=9.3 \text { to } 56 \cdot 10^{14} \mathrm{~g}
\end{aligned}
$$

TABLE III. Turnover number (TN) of RuBPcase (kat.mole ${ }^{-1}$ ), assuming a molecular

\begin{tabular}{|c|c|c|c|c|}
\hline $\begin{array}{l}\text { Measurement } \\
\text { conditions }\end{array}$ & Plant & & $T N$ & Reference \\
\hline $\begin{array}{c}\text { In vitro } \\
" 1 \\
" \\
" \\
"\end{array}$ & $\begin{array}{l}\text { Spinach } \\
" \\
" \\
\text { Barley }\end{array}$ & $\begin{array}{r}18 \\
14 \\
17 \\
8 \\
15\end{array}$ & $\begin{array}{l}-37 \\
-16 \\
-32 \\
-9 \\
-32\end{array}$ & $\begin{array}{l}\text { Ellis, } 1977 \\
\text { Hall et al., } 1981 \\
\text { Berhow et al., } 1982 \\
\text { Johal, Bourque, } 1979 \\
\text { Berhow et al., } 1982\end{array}$ \\
\hline $\begin{array}{l}\text { Saturating substrato } \\
\text { concentrations } \\
\text { Natural conditions }\end{array}$ & & $1 t$ & $\begin{array}{r}17 \\
3.3 \\
\text { to } 3.3\end{array}$ & $\begin{array}{l}\text { Ellis, } 1979 \\
\text { Ellis, } 1979 \\
\text { Wildner, } 1981\end{array}$ \\
\hline
\end{tabular}
weight of 550 o0o daltons.

\section{CONCLUDING REMARKS}

The present model of plant productivity allows the connection of data on the amount and turnover number of RuBPcase of photosynthetic apparatus and data on carbon dioxide assimilation by a canopy. Such a model should allow a better understanding of the mechanisms and of the limitations of carbon dioxide assimilation by a canopy. It could also be used as a model for leaf protein productivity.

World production of cereals was $17 \cdot 10^{14} \mathrm{~g}$ in 1981 (FAO, 1982). Their protein content is about $8 \%$ (Demarquilly et al., 1978). World cereal protein production was thus $14 \cdot 10^{13} \mathrm{~g}$ in 1981 . The amount of leaf protein on the Earth is thus about ten times higher than the yearly cereal protein production.

The estimate of leaf protein in a canopy allows the evaluation of other leaf components and specially those of chloroplasts as far as their ratio to leaf proteins is known. Thus the world amount of RuBPcase may be evaluated assuming either a $C_{3}$ type or a $C_{4}$ type carbon dioxide assimilation. According to the above estimation of leaf proteins and to the data of table II, the estimate ranges from 8.6 to $90.10^{13} \mathrm{~g}$ for a $C_{3}$ type or from 2.6 to $25 \cdot 10^{13} \mathrm{~g}$ for a $C_{4}$ type. These values are higher than the $4 \cdot 10^{13} \mathrm{~g}$ computed by Ellis (1979) who 


\section{IV.2.168}

used net instead of gross primary productivity and estimated $\tau$ at 0.5 year (Personal communication).

\section{REFERENCES}

Berhow MA, Saluja A and MC Fadden BA (1982) Rapid purification of D-Ribulose1,5-bisphosphate carboxylase by vertical sedimentation in a reoriented gradient, Plant Sci. Lett. 27, 51-57.

Box $\mathrm{E}$ and Lieth $\mathrm{H}$ (1977) Geographical dimensions of terrestrial net and gross primary productivity : a first attempt. European seminar on biological solar energy conversion systems. Grenoble, France.

Demarquilly C, Andrieu $J$ and Sauvant D (1978) Tableaux de la valeur nutritive des aliments. In INRA ed. Alimentation des ruminants, pp 519-555. Versailles, France.

Ellis RJ (1979) The most abundant protein in the world, Trends biochem. Sci. $4,241-244$.

FAO (1982) Production yearbook 35, FAO p 85 . Rome, Italy.

Hall NP, Mc Curry SD and Tolbert NE (1981) Storage and maintaining activity of ribulose bisphosphate carboxylase/oxygenase, Plant Physiol. 67,1220-1223.

Johal S and Bourque DP (1979) Crystalline ribulose-1,5-bisphosphate carboxylase/oxygenase from spinach, Science 204, 75-76.

Joyard J (1979) L'enveloppe des chloroplastes. THèse de doctorat es sciences naturelles. Université scientifique et médicale de Grenoble.

Kira T (1975) Primary production of forests. In Cooper JP, ed. Photosynthesis and productivity in different environnements, pp 5-40. London, England : Cambridge University Press.

Ku MSB, Schmitt MR and Edwards GE (1979) Quantitative determination of RuBP Carboxylase-Oxygenase protein in leaves of several $C_{3}$ and $C_{4}$ plants, $J$. exp Bot. 30, 89-98.

Pheloung P and Brady CJ (1979) Soluble and fraction 1 protein in leaves of $C_{3}$ and $\mathrm{C}_{4}$ grasses, J. Sci. Food Agric. 30, 246-250.

Ruget $\mathrm{F}$ (1981 a) Respiration de croissance et respiration d'entretien : méthodes de mesure, comparaison des résultats, Agronomie 1, 601-610.

Ruget $F(1981$ b) Respiration de croissance et d'entretien du Mais dans différentes conditions artificielles de culture, Agronomie 1, 845-852. Singer SJ, Egginan L, CampbelI JM and Wildmän SG (1952) The proteins of gxeen leaves IV a high molecular weight protein comprising a large part of the cytoplasmic proteins, J. Biol. Chem. 97, 233-239.

wildner GF. (1981) Ribulose-1,5-bisphosphate carboxylase-oxygenase aspects and prospects, Physiol. Plant. 52, 385-389.

Woodwell GM (1978) The carbon dioxide question, Sci. Am. 238, 34-43.

Yamaguchi $J$ (1978) Respiration and the growth efficiency in relation to crop productivity, J. Fac. Agric. Hokkaido Univ.. 59, 59-129.

Yeoh $\mathrm{HH}$, Stone NE and Watson L (1982) Taxonomic variation in the subunit amino acid composition of RuBPcarboxylases from grasses, Phytochem. 21,71-80.

\section{ACKNOLEDGEMENTS}

The author wishes to express his gratitude to $\mathrm{C}$. Varlet-Grancher for invaluable help in the preparation of this communication.

Author address : R. Douillard, Laboratoire de Biochimie et Technologie des Protêines, INRA, La Géraudière, 44072 Nantes Cédex, France. 